\title{
White clover ecotype germplasm from the USA for development of New Zealand and overseas cultivars
}

\author{
K.H. WIDDUP ${ }^{1}$, J.R. CARADUS ${ }^{2}$, J. GREEN ${ }^{3}$, J.P. MUELLER ${ }^{3}$; C.P. PENNELL ${ }^{1}$ \\ ${ }^{1}$ AgResearch Lincoln, New Zealand \\ ${ }^{2}$ AgResearch Grasslands, Palmerston North, New Zealand \\ ${ }^{3}$ North Carolina State University, Raleigh, USA
}

\section{Abstract}

An ecotype collection of 98 populations of white clover (Trifolium repens L.) from pastures in the eastern USA together with five USA Ladino and five New Zealand cultivars were grown in grass swards at Raleigh, North Carolina; Palmerston North and Lincoln, New Zealand. The material was compared for leaf size, cyanogenesis, seasonal growth, \% clover cover and persistence. When examined as a single group, the USA ecotypes consisted of a wide range of plant types from small-leaved acyanogenic to large-leaved cyanogenic types. This contrasted with the uniformly large-leaved acyanogenic USA Ladino cultivars which have been the principal cultivars sown in eastern USA. Various selection pressures over time together with introgression between Ladino and resident wild clover types has resulted in a wide array of plant types. At the North Carolina site, USA ecotype material generally demonstrated better growth and persistence compared to the USA Ladino and New Zealand cultivars. The best ecotype plots from the Piedmont (inland region) had 55\% clover cover by the third spring compared to $12 \%$ cover from the USA cultivar, SRVR and $2 \%$ cover from the NZ cultivar, Huia. Selective pressures such as hot summers, viruses, root-feeding pests and other stresses on the local clover types have resulted in ecotype material with improved adaptive features. The USA ecotype collection is an important source of germplasm for development of improved white clovers for the eastern USA. At the New Zealand sites, the USA material demonstrated pooraverage yields compared to NZ cultivars. However, a small set of USA ecotypes showed good recovery following the dry 1995 summer at Lincoln and this material warrants closer examination to determine the adaptive mechanisms involved. As the USA ecotypes show a general lack of adaptation to New Zealand pastures, any desirable features such as heat tolerance, deeper nodal roots or virus resistance uncovered in this material will require hybridisation and backcrossing with selected elite New Zealand material to capture the benefits.

Keywords: adaptation, eastern USA, ecotype populations, plant evaluation, variation, white clover

\section{Introduction}

In recent years, development of improved white clover has widened from a national focus to an international focus. New Zealand exports clover seed to countries in temperate regions throughout the world and produces over 50\% of world requirements (Mather et al. 1996). In the past, New Zealand relied on the wide adaptation and acceptability of Grasslands Huia white clover for overseas markets. However, it is a unrealistic to expect Huia to retain this position and achieve high agronomic performance in all overseas conditions where white clover is used. Recent evaluations of New Zealand white clover cultivars in the USA for example, have shown poor growth and persistence compared to USA cultivars (Widdup 1993). In future, for New Zealand to maintain its position as producer of top quality white clover cultivars internationally, it must develop cultivars which are adapted to various regions of the world.

White clover has been an important pasture legume in the USA. It was first introduced into the United States by Europeans in the seventeenth Century (Leffel \& Gibson 1973) and successfully colonised the eastern and northern regions of America. In the 1950s, largeleaved Ladino types were introduced from Italy and large areas of eastern and northern USA were sown with these types. The Ladino cultivars were initially very successful (Chamblee 1983) but there are now several million acres of pasture in eastern USA, where white clover has become sparse, unproductive and persists only 3-4 years in a new pasture. The lack of persistence and unreliability of clover has been related to the hot summers and a virus-pest complex as the main causal factor for poor persistence (Pederson et al. 1991). USA improvement programmes have been based on resistance to this virus-pest complex using Ladino-based genetic material, but persistence has not greatly improved.

Persistence has also been a major component in New Zealand improvement programmes. Natural ecotype material has proved an extremely important genetic source for improved persistence in New Zealand (Widdup \& Boleyn 1986; Williams et al. 1982). A similar strategy of using locally adapted ecotype material to improve clover persistence is proposed for the eastern and northern USA regions. The objective is to (1) develop cultivars 
better adapted and persistent in the USA and to (2) gain new white clover germplasm with important genetic features for New Zealand improvement programmes.

This paper describes early results of ecotype white clover populations collected from eastern USA and evaluated in North Carolina, USA, and Palmerston North and Lincoln, New Zealand.

\section{Materials and methods}

\section{Population collection}

During the northern hemisphere summer, June-August 1992, seed was collected from ecotype populations of white clover in the eastern USA. The collection covered areas from Mississippi $\left(30^{\circ} \mathrm{N}\right)$ in the south, through the States east of the Appalachian divide to Pennsylvania in the north $\left(43^{\circ} \mathrm{N}\right)$. This region covers latitudes similar to New Zealand, but with far greater extremes of summer temperature (up to $38^{\circ} \mathrm{C}$ ) and winter cold (down to $-20^{\circ} \mathrm{C}$ ).

Local extension advisers assisted in identifying farms with pastures greater than 15 years old which were predominantly grazed. Most pastures sampled were grazed by cattle, however, many upland sites on the Appalachians were grazed by sheep. The clover was most prevalent in pastures where management conditions had favoured white clover development. These conditions included short grazed pastures where grass competition was reduced, little or no use of fertiliser nitrogen and no herbicide control of broadleaf weeds. At each collection site, seed was sampled from individuals randomly across a pasture. One to five seed heads were taken per individual, from 50-60 individuals. The full list of populations and details of the collection sites are detailed in an Overseas Travel Report (Widdup 1993).

\section{Evaluation trials}

The 98 populations collected from eastern USA together with five USA Ladino cultivars and five New Zealand cultivars were compared at Raleigh, North Carolina, USA (latitude $35^{\circ} \mathrm{N}$ ), at Palmerston North, (latitude $40^{\circ} \mathrm{S}$ ) and at Lincoln $\left(44^{\circ} \mathrm{S}\right)$, New Zealand. Raleigh has a hot temperate climate (annual rainfall $1600 \mathrm{~mm}, 30^{\circ} \mathrm{C}$ mean summer temperature, $5^{\circ} \mathrm{C}$ mean winter temperature); Palmerston North, a warm temperate climate (995 $\mathrm{mm}, 18^{\circ} \mathrm{C}, 8^{\circ} \mathrm{C}$ ) and Lincoln a dry warm temperate climate $\left(665 \mathrm{~mm}, 17^{\circ} \mathrm{C}, 6^{\circ} \mathrm{C}\right)$. At each site, plants of each population/cultivar were inserted into an existing grass sward cleared of white clover, in 10-plant rows with $10 \mathrm{~cm}$ between plants. The trials were randomised block designs with five replications. The North Carolina site was established in April (spring) 1993, the Lincoln site in October (spring) 1993 and Palmerston North in April (autumn) 1994.

Plant characters visually scored included percentage row cover by clover, seasonal growth, spread of stolons and recovery following summer drought on a 0-9 scale. A persistence index was calculated using the ratio: final growth score/first growth score $* 100$. The picrate test (Corkill 1940) was used to determine the percentage of cyanogenic genotypes per population and the cyanogenic intensity of plants on a $0-5$ scale. The cyanogenic level and leaf size $(\mathrm{mm})$ were only assessed at Palmerston North. The scores for each character at each site were analysed by analysis of variance using a randomised complete block design. The trial sites were grazed following plant assessments with cattle at North Carolina and sheep at Palmerston North and Lincoln.

\section{Results}

The level of plant cyanogenesis and leaf size were used to characterise the eastern USA ecotype populations and control cultivars. The ecotypes covered the full range of plant types from small-leaved acyanogenic to large-leaved cyanogenic types (Figure 1). No distinct

Figure 1: Cyanogenesis level and leaf size as indicators of plant variation in eastern USA ecotypes, USA cultivars and NZ cultivars

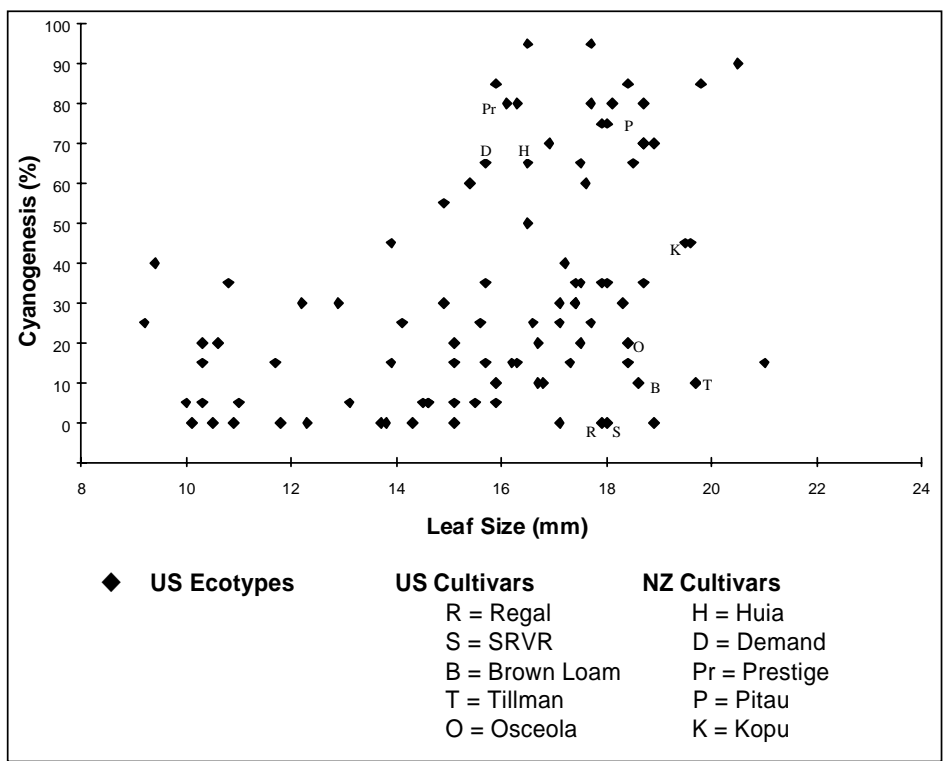


Table 1: Means and standard errors for cyanogenesis, leaf size and clover growth based on geographical origin of populations and cultivars.

\begin{tabular}{|c|c|c|c|c|c|c|c|}
\hline Plant Character & South & Coastal & Piedmont & Mountain & North & USAcv. & NZcv. \\
\hline Number of populations & 13 & 13 & 39 & 23 & 9 & 5 & 5 \\
\hline $\begin{array}{l}\text { Cyanogenesis \% plants } \\
\text { Leaf width }(\mathrm{mm})\end{array}$ & $\begin{array}{c}53 \pm 8 \\
17.0 \pm 0.4\end{array}$ & $\begin{array}{c}40 \pm 8 \\
17.5 \pm 0.4\end{array}$ & $\begin{array}{c}40 \pm 5 \\
17.2 \pm 0.3\end{array}$ & $\begin{array}{c}12 \pm 3 \\
12.9 \pm 0.6\end{array}$ & $\begin{array}{c}14 \pm 4 \\
12.8 \pm 0.6\end{array}$ & $\begin{array}{c}13 \pm 10 \\
18.7 \pm 0.5\end{array}$ & $\begin{array}{c}67 \pm 6 \\
17.2 \pm 0.7\end{array}$ \\
\hline $\begin{array}{l}\text { North Carolina, USA } \\
\text { \% clover cover } \\
\text { Spring } 1994 \\
\text { Spring } 1995\end{array}$ & $\begin{array}{l}78 \pm 5 \\
17 \pm 3\end{array}$ & $\begin{array}{l}81 \pm 3 \\
30 \pm 5\end{array}$ & $\begin{array}{l}84 \pm 2 \\
35 \pm 3\end{array}$ & $\begin{array}{l}64 \pm 5 \\
19 \pm 3\end{array}$ & $\begin{array}{l}66 \pm 5 \\
16 \pm 3\end{array}$ & $\begin{array}{c}60 \pm 15 \\
9 \pm 3\end{array}$ & $\begin{array}{l}45 \pm 5 \\
2 \pm 0.2\end{array}$ \\
\hline Persistence * & $30 \pm 5$ & $40 \pm 6$ & $50 \pm 3$ & $37 \pm 5$ & $30 \pm 5$ & $25 \pm 7$ & $4 \pm \pm 1$ \\
\hline $\begin{array}{l}\text { Palmerston North, NZ } \\
\text { Growth (0-9) } \\
\text { Spring } 1994 \\
\text { Winter } 1995\end{array}$ & $\begin{array}{l}4.1 \pm 0.1 \\
3.4 \pm 0.4\end{array}$ & $\begin{array}{l}4.7 \pm 0.2 \\
4.3 \pm 0.4\end{array}$ & $\begin{array}{l}4.5 \pm 0.1 \\
3.6 \pm 0.1\end{array}$ & $\begin{array}{l}3.3 \pm 0.2 \\
2.0 \pm 0.2\end{array}$ & $\begin{array}{l}3.3 \pm 0.3 \\
1.8 \pm 0.3\end{array}$ & $\begin{array}{l}5.2 \pm 0.2 \\
4.2 \pm 0.4\end{array}$ & $\begin{array}{l}5.3 \pm 0.3 \\
4.7 \pm 0.3\end{array}$ \\
\hline Persistence * & $82 \pm 9$ & $92 \pm 8$ & $82 \pm 3$ & $62 \pm 5$ & $55 \pm 8$ & $82 \pm 11$ & $90 \pm 8$ \\
\hline $\begin{array}{l}\text { Lincoln, NZ } \\
\text { Growth (0-9) } \\
\text { Spring 1993 } \\
\text { Spring } 1995\end{array}$ & $\begin{array}{l}5.4 \pm 0.4 \\
2.0 \pm 0.2\end{array}$ & $\begin{array}{l}5.8 \pm 0.3 \\
2.3 \pm 0.3\end{array}$ & $\begin{array}{l}5.7 \pm 0.2 \\
2.3 \pm 0.5\end{array}$ & $\begin{array}{l}5.5 \pm 0.2 \\
2.7 \pm 0.3\end{array}$ & $\begin{array}{l}5.3 \pm 0.3 \\
2.4 \pm 0.4\end{array}$ & $\begin{array}{l}4.5 \pm 0.6 \\
1.9 \pm 0.2\end{array}$ & $\begin{array}{l}6.2 \pm 0.6 \\
2.7 \pm 0.6\end{array}$ \\
\hline Persistence * & $37 \pm 6$ & $40 \pm 5$ & $40 \pm 3$ & $49 \pm 5$ & $45 \pm 6$ & $42 \pm 7$ & $44 \pm 9$ \\
\hline
\end{tabular}

* Persistence Index = Final Score/First Score *100

plant type typified the eastern USA region, instead a continuum of clover types was evident. In contrast, the USA cultivars were uniformly large leaved and acyanogenic ladino types. The New Zealand cultivars were medium-large leaved, cyanogenic types.

The ecotype populations were divided into five groups on the basis of latitude and altitude of origin (Table 1). The 'South' represented ecotypes from Mississippi $\left(30^{\circ}-33^{\circ} \mathrm{N}\right)$; 'Coastal', coastal areas of North Carolina and Virginia $\left(32^{\circ}-37^{\circ} \mathrm{N}\right)$; 'Piedmont', inland areas of Georgia, North Carolina and Virginia $\left(32^{\circ}-\right.$ $37^{\circ} \mathrm{N}$ ); 'Mountain' areas on the Appalachians and 'North', areas in Pennslyvania $\left(38^{\circ}-42^{\circ} \mathrm{N}\right)$.

Examination of plant type showed that cyanogenesis level was high in ecotypes from the south, intermediate in ecotypes from the Coastal/Piedmont regions and low in ecotypes from the Mountain and Northern regions (Table 1). The ecotypes also indicated declining leaf size with increasing latitude and altitude.

In the evaluation trial at the North Carolina site (Piedmont region), all the white clovers showed good performance for the first eighteen months then declined rapidly over the second summer (Figure 2a). The mean of all the USA ecotype material as a group, demonstrated similar growth and persistence to the best USA cultivar, SRVR (Southern Regional Virus Resistant). However, when comparing material, the USA ecotypes from the Coastal and Piedmont regions had superior growth and persistence compared to ecotypes from the Southern, Mountain, Northern regions and to the USA Ladino cultivars (Table 1). The best ecotype material showed good recovery after the second summer (Figure 2a). All the New Zealand cultivars including Huia showed poor growth and persistence (Table 1, Figure 2a).

At the Palmerston North site, conditions were favourable for white clover growth during 1994/1995. The mean of all the USA ecotype material as a group had inferior growth to the New Zealand cultivar, Huia (Figure $2 b)$. However, the USA ecotypes from the Coastal region showed higher growth and persistence compared to all other ecotypes (Table 1) and were similar to the USA Ladino cultivars. The Mountain and Northern region ecotypes were unproductive and non-persistent. Superior ecotypes from the Coastal region were identified which had improved yields by the last assessment (Figure 2b).

At the Lincoln site, conditions for white clover growth were favourable in summer 1994 but were hot and dry in summer 1995, resulting in poor recovery of clover in autumn 1995. The USA ecotypes from all the regions together with the USA cultivars showed similar growth and persistence (Table 1) but were generally inferior to NZ cultivars including Huia (Figure 2c). Some ecotype material from the Piedmont region demonstrated superior autumn recovery compared to Huia following the second summer (Figure 2c).

\section{Discussion}

The USA ecotype collection consisted of a wide range of plant types forming a continuum from small-leaved 
acyanogenic types through to large-leaved cyanogenic types. This range of plant types is similar to the collection made in south west Europe (Caradus et al. 1990). There was an expectation that large-leaved acyanogenic Ladino types would have dominated the collection as Ladino cultivars have been the principal cultivars sown in USA pastures for over 50 years. However, only 10 of the 98 ecotype populations had Ladino-type characteristics. Different selective pressures throughout the eastern USA region combined with introgression between Ladino types and the resident 'wild' white clover have resulted in an array of plant types, but with a trend toward smallmedium leaved types and a low-moderate level of cyanogenesis.

The eastern USA region was divided into five geographical areas based on latitude and altitude. The cyanogenesis level and leaf size of the ecotype populations was greatest at the low latitude and altitude (warmest regions) and declined with increasing latitude and altitude (coldest regions). This result is similar to collections made in Europe and the Mediterranean (Davies \& Young 1967; Caradus et al. 1990). There was, however, considerable variation between plants within each population.

The USA ecotypes as a group showed better persistence at the North Carolina site than the USA Ladino and New Zealand cultivars. All the clovers declined markedly in the second summer but by the third year, the ecotype material showed superior cover to the control cultivars. The best ecotype collected from the Piedmont region (inland area), produced 55\% clover cover in plots in the third spring compared to $12 \%$ cover for the USA cultivar, SRVR and $2 \%$ cover for the NZ cultivar, Huia. Selective pressure on the resident clovers over time such as hot summers, diseases such as alfalfa mosaic virus and peanut stunt virus (Barnett \& Gibson 1975), pests such as root curculio, Sitona hispidula (Powell et al. 1983), poor grazing management and other stresses has resulted in ecotype material with improved adaptive features. In depth studies of the ecotype material would be required to better understand the adaptive mechanisms involved. However, the USA ecotype collection represents an important source of germplasm for future development of white clovers with improved persistence in eastern USA.

There was a large genotype $\mathrm{x}$ environment interaction shown by the USA and NZ clover material. The poor adaptation of NZ cultivars to the USA environment reflects the result of cultivar development under cooler conditions, with different diseases and pests and intensive sheep rather than cattle grazing. Likewise, the USA ecotypes as a group, have shown average-poor yields and persistence at the New Zealand sites compared to the local New Zealand cultivars. This is not an
Figure 2: White clover performance (1993-95) of the mean of the USA ecotypes, the best USA ecotype population, the USA cultivar, SRVR and the NZ cultivar, Huia at three sites:
A. Percentage white clover cover at North Carolina, USA
B. Relative growth $($ Huia $=100)$ at Palmerston North, $\mathrm{NZ}$
C. Relative growth $(\mathrm{Huia}=100)$ at Lincoln, NZ

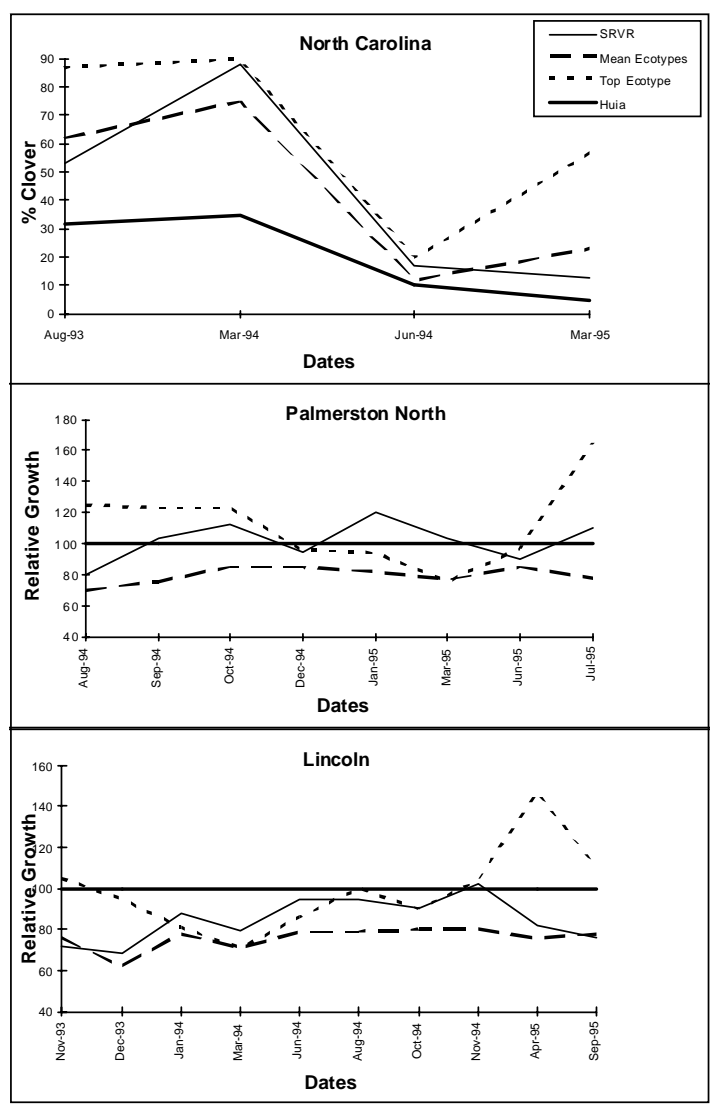

unexpected result, and emphasis was placed on recognising introduced ecotype material with plant characteristics conferring improved adaptation to the summer stresses experienced in eastern areas of New Zealand. Following the hot dry summer at the Lincoln site in 1995, the best USA ecotype populations showed better recovery in April (Figure 2c) compared to Huia. The reason for the good recovery was not apparent but may be linked to deeper nodal roots and/or heat tolerance. Further study is required to determine the adaptive mechanism.

In order to capture the tolerance to summer stresses shown by some of the USA ecotypes but without the added lack of adaptation to NZ pastoral conditions, it 
will be necessary to hybridise and backcross the USA ecotypes to selected NZ material. In particular, selected USA ecotypes will be combined with NZ dryland ecotypes and elite NZ cultivars. This will allow development of new recombinants with unrelated but desirable genes to be incorporated in New Zealand's dryland white clover improvement programme.

\section{References}

Barnett, O.W.; Gibson, P.B. 1975. Identification and prevalence of white clover viruses and the resistance of Trifolium species to these viruses. Crop Science 15: $32-37$.

Caradus, J.R.; Forde, M.B.; Wewala, S.; Mackay, A.C. 1990. Description and classification of a white clover (Trifolium repens L.) germplasm collection from southwest Europe. New Zealand Journal of Agricultural Research 33: 367-375.

Chamblee, D.S.; Lucas, L.T.; Campbell, W.V. 1983: Ladino clover persistence as affected by physical management and use of pesticides. Proceedings International Grassland Congress 14: 584-587.

Corkill, L. 1940. Cyanogenesis in white clover (Trifolium repens L.) I. Cyanogenesis in single plants. New Zealand Journal of Science and Technology 22B: 65-67.

Davies, W.E.; Young, N.R. 1967. The characteristics of European, Mediterranean and other populations of white clover (Trifolium repens L.). Euphytica 16: 330-340.
Leffel, R.C.; Gibson, P.B. 1973. White clover. pp. 167176. In: Heath, M.E. et al. (eds). Forages: The Science of Grassland Agriculture. Third Edition.

Mather, R.D.J.; Melhuish, D.T.; Herlihy, M. 1995. Trends in global marketing of white clover cultivars. Agronomy Society of New Zealand Special Publication No. 11/Grassland Research and Practice Series No. 6: 7-14.

Pederson, G.L.; Windham, G.L.; Ellsbury, M.M.; McLaughlin, M.R.; Pratt, R.G.; Brink, G.E. 1991. White clover yield and persistence as influenced by Cypermethrin, Benomyl and root-knot nematode. Crop Science 31: 1297-1302.

Powell, G.S.; Campbell, W.V.; Cope, W.A.; Chamblee, D.S. 1983. Ladino clover resistance to the root curculio (Coleoptera: Curculionidae). Journal of Entomology 76: 264-268.

Widdup, K.H.; Boleyn, J.M. 1986. Improved performance from screening and hybridising of white clover germplasm in Southland. Agronomy Society of New Zealand Special Publication 5: 301-305.

Widdup, K.H. 1993. White clover ecotype collection of persistent germplasm from southern USA. Overseas Travel Report, AgResearch. 36 pp.

Williams, W.M.; Lambert, M.G.; Caradus, J.R. 1982. Performance of a hill country white clover selection. Proceedings of New Zealand Grassland Association 43: 188-195. 
